\title{
Initiation Steps for the Polymerization of Vinyl Ethers Promoted by Cationic Palladium Aqua Complexes
}

\author{
Chi-Li Chen, Yi-Chun Chen, Yi-Hong Liu, Shie-Ming Peng, and \\ Shiuh-Tzung Liu* \\ Department of Chemistry, National Taiwan University, Taipe, Taiwan 106, Republic of China
}

Received August 14, 2002

\begin{abstract}
Both deuterium-label ed experimental and NMR spectroscopic analyses of poly(vinyl ether) offer the mechanistic insight into the polymerization, indicating that the cationic palladium aqua imine-phosphine complexes $\left[(\mathbf{P} \sim \mathbf{N}) \mathrm{PdMe}\left(\mathrm{H}_{2} \mathrm{O}\right)\right] \mathrm{BF}_{4}\left(\mathbf{P} \sim \mathbf{N}=\mathrm{o}_{-} \mathrm{C}_{6} \mathrm{H}_{4}\left(\mathrm{PPh}_{2}\right)(\mathrm{N}=\mathrm{CHAr})\right)$ promote the reaction via proton-transfer initiation. Insertion of vinyl ether into the $\mathrm{Pd}-\mathrm{Me}$ bond in $\left[(\mathbf{P} \sim \mathbf{N}) \mathrm{PdMe}_{(}\left(\mathrm{H}_{2} \mathrm{O}\right)\right] \mathrm{BF}_{4}$ does not proceed, but the single insertion of the same substrate into the $\mathrm{Pd}$-acetal bond of $\left[(\mathbf{P} \sim \mathbf{N}) \mathrm{PdCOCH}_{3}(\mathrm{~L})\right] \mathrm{BF} \mathrm{F}_{4}$ provides the stable inserted product $\left[(\mathbf{P} \sim \mathbf{N}) \mathrm{PdCH}(\mathrm{OEt}) \mathrm{CH}_{2} \mathrm{COCH}_{3}\right] \mathrm{BF}_{4}$, which has been characterized by an X-ray structural determination. However, these palladium complexes do not catalyze the polymerization or copolymerization of vinyl ether and carbon monoxide.
\end{abstract}

\section{Introduction}

Utilization of a Lewis acid, particularly with earlytransition-metal complexes, to promote the carbocationic polymerization of vinyl ethers is well-documented, ${ }^{1-8}$ but the use of late-transition-metal complexes as catalysts on such polymerization is rarely reported. ${ }^{1 a, b, 6}$ Recently, Brookhart and Eisenberg's groups reported that the polymerization of vinyl ethers could be catalyzed by palladium ${ }^{1 a}$ and platinum ${ }^{6}$ di imine complexes, respectively. In our earlier investigation, cationic complexes $\mathbf{1}$ and $\mathbf{2}$ were also excellent catalysts for such

* To whom correspondence should be addressed. E-mail: stliu@ ccms.ntu.edu.tw.

(1) (a) Ittel, S. D.; J ohnson, L. K.; Brookhart, M. Chem. Rev. 2000, 100, 1169. (b) Baird, M. C. Chem. Rev. 2000, 100, 1471. (c) Coates, G. W. Chem. Rev. 2000, 100, 1223. (d) Chen, E. Y.-X.; Marks, T.J . Chem. Rev. 2000, 100, 1391. (e) Boffa, L. S.; Novak, B. M. Chem. Rev. 2000, 100, 1479. (f) Siemeling, U. Chem. Rev. 2000, 100, 1495 and references therein.

(2) (a) Sawamoto, M.; Higashimura, T. Makromol . Chem., Macromol Symp. 1992, 60, 47. (b)'Kennedy, J. P. Macromol. Chem. 1990, 1, 260. (c) Kazanskii, K. Makromol. Chem., Macromol. Symp. 1992, 60, 259. (d) Aoshima, S.; Kobayashi, E. Makromol. Chem., Macromol. Symp. 1995, 95, 91. (e) Patrickios, C. S.; Forder, C.; Armes, S. P.; Billingham, N. C. J . Polym. Sci., Part A: Polym. Chem. 1997, 35, 1181. (f) Pugh, C.; Kiste, A. L. Prog. Polym. Sci. 1997, 22, 601. (g) Spange, S.; Eismann, U.; Hoehne, S.: Langhammer, E. Macromol. Symp. 1998, 126, 223. (h) Yamada, K.; Miyazaki, M.; Ohno, K.; Fukuda, T.; Minoda, M. Macromolecules 1999, 32, 290. (i) Matsuzaki, K.; I to, H.; Kawamura, T.; Uryu, T. J. Polym. Sci., Polym. Chem. Ed. 1979, 11, 971.

(3) Higashimura, T.; Sawamoto, M. In Comprehensive Polymer Science; Eastmond, G. C., Ledwith, A., Russo, S., Sigwait, P., Eds.; Pergamon Press: New York, 1989; Vol. 3, p 673.

(4) (a) J ohnson, L. F.; Heastley, F.; Bovey, F. A. Macromolecules 1970, 3, 175. (b) Nuyken, O.; Aechtner, S. Polym. Bull. 1992, 28, 117. (c) Fumio, S.; Mitsu, M. Macromolecules 1995, 28, 6911.

(5) Wang, Q.; Baird, M. C. Macromolecules 1995, 28, 8021.

(6) Albietz, P. J ., J r.; Yang, K.; E isenberg, R. Organometallics 1999, 18, 2747.

(7) (a) Chen, Y.-C.; Reddy, K. R.; Liu, S.-T. J . Organomet. Chem. 2002, 656, 198. (b) Reddy, K. R.; Surekha, K.; Lee, G.-H.; Peng, S.-M.; Chen, J .-T.; Liu, S.-T. Organometallics 2001, 20, 1292. (c) Chen, Y.C.; Chen, C.-L.; Chen, J .-T.; Liu, S.-T. Organometallics 2001, 20, 1285. (d) Reddy, K. R.; Tsai, W.-W.; Surekha, K.; Lee, G.-H.; Peng, S.-M.; Chen, J .-T.; Liu, S.-T. J . Chem. Soc., Dalton Trans. 2002, 1776. (e) Reddy, K. R.; Chen, C.-L.; Liu, Y.-H.; Peng, S.-M.; Chen, J .-T.; Liu, S.-T. Organometallics 1999, 18, 2574.

(8) Sen, A. Acc. Chem. Res. 1988, 21, 421.

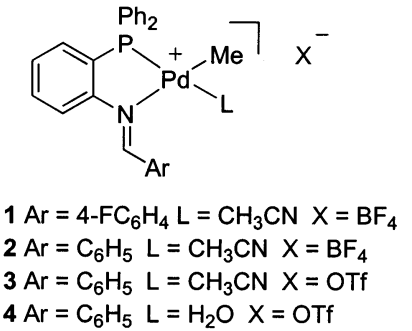

polymerization. ${ }^{7 a}$ In these studies the mechanism for polymerization was attributed to the cationic pathway based on the end-group analysis and solvent effect. ${ }^{4-8}$ However, the initiation of polymerization still remains an interesting aspect. It is suggested that the cationic metal center might initiate the carbon-carbon bond formation by heterolytic cleavage of the $\pi$-bond of the olefin followed by an addition process. ${ }^{8} \mathrm{Here}$, we report our effort to determine the mechanistic pathway for the polymerization and hydrolysis of vinyl ether catalyzed by palladium phosphine-imine complexes.

\section{Results and Discussion}

Polymerization of ethyl vinyl ether is carried out in a dichloromethane solution of monomer with the palladium complex as the catalyst at $30^{\circ} \mathrm{C}$ under a nitrogen atmosphere but not absolutely dry conditions (see below). Results of the polymerization of ethyl vinyl ethers catalyzed by cationic palladium complexes are summarized in Table 1. In all instances, the palladium complexes catalyze the polymerization with excellent conversions. The molecular weights of poly(vinyl ether) are around 8000, whereas poly(dihydrofuran) weights are in the range of $16000-20000$. It is interesting to find that all of the polymerization reactions require an induction period, but less time is needed for the hydrate complex 4. In fact, the aqua-coordinated complex 4 initiates the polymerization within several minutes, whereas the corresponding acetonitrile-coordinated com- 
Table 1. Polymerization of Vinyl Ethers ${ }^{a, b}$

\begin{tabular}{cccccrrr}
\hline entry & monomer & catalyst & $\begin{array}{l}\text { time } \\
(\mathrm{h})\end{array}$ & $\begin{array}{c}\text { conversn } \\
(\%)\end{array}$ & \multicolumn{1}{c}{$\mathrm{M}_{\mathrm{N}}$} & PDIc \\
\hline 1 & ethyl vinyl ether & $\mathbf{2}$ & 2 & 100 & 8476 & 3.32 \\
2 & 2,3-dihydrofuran & $\mathbf{2}$ & 1.5 & 98 & 20359 & 2.40 \\
3 & ethyl vinyl ether & $\mathbf{3}$ & 1.8 & 94 & 7139 & 3.20 \\
4 & ethyl vinyl ether & $\mathbf{4}$ & 1.8 & 92 & 7983 & 3.19 \\
5 & ethyl vinyl ether & $\mathbf{4}$ & 2 & 100 & 7598 & 3.39 \\
6 & 2,3-dihydrofuran & $\mathbf{4}$ & 2 & 99 & 16721 & 2.89 \\
7 & 2,3-dihydrofuran & $\mathbf{4}$ & 1.5 & 98 & 17909 & 2.77
\end{tabular}

a Conditions: vinyl ether $(2 \mathrm{~mL})$, palladium complex $(10 \mathrm{mg})$ in $\mathrm{CH}_{2} \mathrm{Cl}_{2}(10 \mathrm{~mL})$ under a nitrogen atmosphere, at $30^{\circ} \mathrm{C} . \mathrm{b}_{\mathrm{N}}$ $\mathrm{M}_{\mathrm{W}}$ by GPC; using THF as eluant at room temperature and polystyrene calibration curve for analyses. ${ }^{\mathrm{C}} \mathrm{PDI}=$ polydispersity index.

plexes 1-3 require $10 \mathrm{~min}$ or more. However, the addition of trace water into the reaction medium with $\mathbf{3}$ as the catalyst shortens the induction period. This induction period is related to the hydrolysis of vinyl ether into acetaldehyde and acetal. In a NMR tube loaded with 4 and ethyl vinyl ether (15 equiv relative to $\mathrm{Pd}$ ) in $\mathrm{CDCl}_{3}$, hydrolysis of vinyl ether takes place at room temperature to form acetaldehyde, 1,1-diethoxyethane (acetal), and ethanol initially. The rationale of this hydrolysis step is due to the Lewis acid nature of the metal complex and the dissociation of water from 4. When the water decreases to $\sim 20 \%$ of the original amount of $\mathbf{4}$ by the NMR integration relative to $\mathrm{Pd}-$ $\mathrm{CH}_{3}$, the polymerization of vinyl ether starts, as evidenced by the appearance of the resonances corresponding to the polymer. In the presence of an excess of water, the reaction yields the hydrolyzed products exclusively. This result clearly illustrates that the rate of hydrolysis is much faster than that of polymerization. It is also noticed that the NMR signals corresponding to the palladium complex stay the same as those of the original complex, particularly without any decrease in the intensity of the $\mathrm{Pd}-\mathrm{CH}_{3}$ resonance. The intact functionality of $\mathrm{Pd}-\mathrm{Me}$ clearly reveals that the polymerization process is not via migratory insertion. Also, only a small fraction of $\mathbf{4}$ is the initiator for the reaction followed by rapid chain growth.

Characterization of polymers was performed by both GPC and NMR. The ${ }^{1} \mathrm{H}$ NMR spectrum of the polymer shows broad signals at $\delta 3.6(\alpha-\mathrm{O}-\mathrm{CH}), 3.48\left(\mathrm{O}-\mathrm{CH}_{2}\right)$, $1.7\left(\beta-\mathrm{CH}_{2}\right)$, and $1.2(-\mathrm{Me})$, typical for the polymer. As expected, the acetal functionality is established as the end groups by the ${ }^{1} \mathrm{H}$ NMR spectrum, which is consistent with the cationic polymerization process. ${ }^{3-6} \mathrm{How}$ ever, it is still not possible to identify the other end group (the initiated side), due to the overlapping of peaks. However, a deuterium-labeling experiment allows us to answer this query. With $\mathbf{3}$ as the catalyst in the presence of trace $\mathrm{D}_{2} \mathrm{O}$, the mass spectrum of the products clearly shows the incorporation of deuterium into the oligomers by $\sim 70 \%$ on the basis of the intensity of $\mathrm{m} / \mathrm{z}$ at $\mathrm{M}+1$ for the formula $\mathrm{H}\left[\mathrm{CH}_{2} \mathrm{CH}(\mathrm{OEt})\right]_{n} \mathrm{OEt}$. In addition, the hydrolysis of ethyl vinyl ether catalyzed by 3 also provides $\mathrm{DCH}_{2} \mathrm{CHO}$ and $\mathrm{DCH}_{2} \mathrm{C}\left(\mathrm{OCH}_{2} \mathrm{CH}_{3}\right)_{2}$, as evidenced by ${ }^{1} \mathrm{H}$ NMR. These results suggest that the proton transfer to vinyl ether is the initiation step for polymerization.

In our previous investigation, the stable chelating product $\mathbf{5}$ of insertion of vinyl acetate into the $\mathrm{Pd}-\mathrm{CH}_{3}$

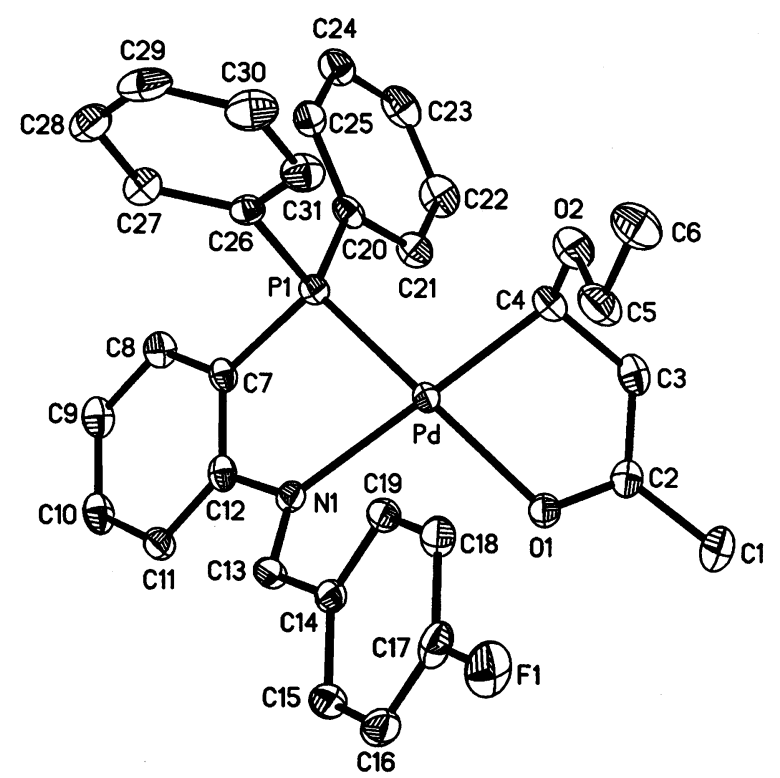

Figure 1. ORTEP plot of the cationic portion of 6 .

bond at room temperature was isolated, ${ }^{7 e}$ but not for ethyl vinyl ether. Concerning the insertion pathway, a<smiles>CCC1OC(C)O[P+]1(c1ccccc1)c1ccccc1</smiles>

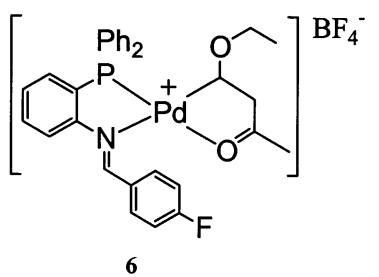

product with a vinyl ether unit inserted into the $\mathrm{Pd}-$ acyl bond was isolated and characterized by singlecrystal analysis. Thus, a mixture of complex 1 (0.18 $\mathrm{mmol})$, vinyl ether $(0.9 \mathrm{mmol})$, and carbon monoxide (50 psi) in dichloromethane $(5 \mathrm{~mL})$ was stirred at room temperature for $12 \mathrm{~h}$. Complex $\mathbf{6}$ was isolated as a light yellow crystalline solid (61\%) and characterized by both spectral and elemental analysis. X-ray-quality crystals of $6 \cdot \mathrm{H}_{2} \mathrm{O}$ were obtained by slow evaporation of a dichloromethane/ether solution. An ORTEP diagram of the cationic portion of $\mathbf{6}$ is shown in Figure 1. The structural study shows that complex $\mathbf{6}$ exists as a slightly distorted square-planar complex with a carbon ligand derived from the insertion of a vinyl ether molecule into $\mathrm{Pd}-\mathrm{COCH}_{3}$. As expected, the carbonyl moiety is coordinated toward the metal center, al lowing the complex to be quite stable through the chelation effect.7e This coordination mode is al so consistent with the infrared absorption of carbonyl stretching at 1621 $\mathrm{cm}^{-1}$. All bond distances and bond angles lie within normal ranges, except $\mathrm{P}(1)-\mathrm{Pd}-\mathrm{N}(1)$ and $\mathrm{O}(1)-\mathrm{Pd}-$ $\mathrm{C}(4)$, illustrated in Table 2 . The smaller angle of $\mathrm{P}(1)-$ $\mathrm{Pd}-\mathrm{N}(1)$ is due to the rigidity of the o-phenylene system and the substituent of the donor atoms, which are similar to those of related complexes previously prepared, ${ }^{7 b-e}$ whereas the smaller angle of $\mathrm{O}(1)-\mathrm{Pd}-\mathrm{C}(4)$ is presumably caused by the chelation effect of the carbon ligand.

However, no further insertion of vinyl ethers takes place with $\mathbf{6}$, and the complex $\mathbf{6}$ does not catalyze the polymerization of vinyl ether. Results of this experiment clearly rule out the possibility of polymerization or 
Table 2. Selected Bond Distances $(\AA)$ and Bond Angles (deg) of 6

$\begin{array}{lllr}\mathrm{Pd}-\mathrm{C}(4) & 2.049(4) & \mathrm{P}(1)-\mathrm{Pd}-\mathrm{N}(1) & 81.7(1) \\ \mathrm{Pd}-\mathrm{N}(1) & 2.195(4) & \mathrm{P}(1)-\mathrm{Pd}-\mathrm{O}(1) & 170.12(9) \\ \mathrm{Pd}-\mathrm{P}(1) & 2.206(1) & \mathrm{N}(1)-\mathrm{Pd}-\mathrm{C}(4) & 178.0(2) \\ \mathrm{Pd}-\mathrm{O}(1) & 2.156(3) & \mathrm{O}(1)-\mathrm{Pd}-\mathrm{C}(4) & 81.8(2) \\ \mathrm{N}(1)-\mathrm{C}(13) & 1.290(6) & \mathrm{O}(1)-\mathrm{C}(2)-\mathrm{C}(3) & 120.0(4) \\ \mathrm{C}(4)-\mathrm{C}(3) & 1.532(7) & \mathrm{Pd}-\mathrm{N}(1)-\mathrm{C}(13) & 127.7(3) \\ \mathrm{C}(3)-\mathrm{C}(2) & 1.481(7) & \mathrm{P}(1)-\mathrm{Pd}-\mathrm{C}(4) & 96.6(2) \\ \mathrm{C}(2)-\mathrm{O}(1) & 1.232(5) & & \end{array}$

Scheme 1<smiles></smiles><smiles></smiles>

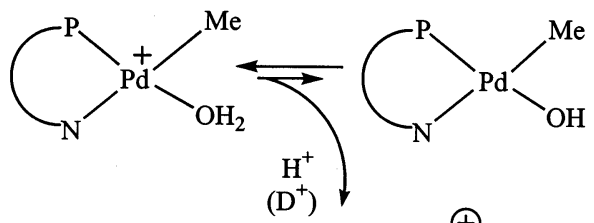

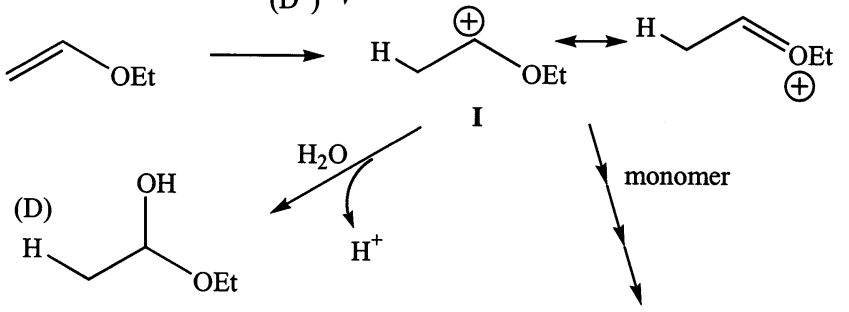

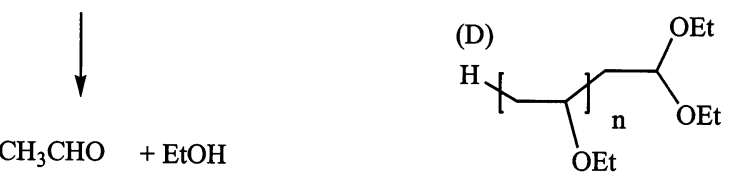

copolymerization of vinyl ether via migratory insertion. It also appears that the palladium center of the coordinated saturated complex $\mathbf{6}$ is not accessible as a site for the coordination of water molecules; i.e., water is not able to compete with the chelating $\mathrm{C}=\mathrm{O}$. Therefore, complex 6 cannot be used as an initiator for the polymerization of vinyl ethers.

A possible polymerization pathway for vinyl ether initiated by palladium complexes is revealed in Scheme 1 , which involves the key step of the proton transfer from the palladium aqua species to vinyl ether. It has been reported that the $\mathrm{pK}_{\mathrm{a}}$ value for $\left[(\mathbf{S C S}) \mathrm{Pd}\left(\mathrm{H}_{2} \mathrm{O}\right)\right]^{+}$ is 10.7. ${ }^{11}$ Thus, the $\mathrm{pK}_{a}$ value of the palladium with an imine donor in $\mathbf{4}$ should be in a similar range, which supports the possibility of the protonation of vinyl ether to generate the oxonium intermediate $\mathbf{I}$, which then undergoes the chain growth with the monomers. As for the hydrolysis of vinyl ether, Kobayashi and co-workers reported that the oxonium intermediate I could be easily hydrolyzed by the catalysis of the palladium complexes, due to its small $\mathrm{pK}_{\mathrm{h}}$ value (hydrolysis constant). ${ }^{10} \mathrm{In}$ other words, the hydrolysis would proceed much faster

(9) Matsuzaki, K.; Ito, H.; Kawamura, T.; Uryu, T. J . Polym. Sci., Polym. Chem. Ed. 1979, 11, 971.

(10) (a) Kobayashi, S.; Nagayama, S.; Busujima, T. J . Am. Chem. Soc. 1998, 120, 8288. (b) Coordination Chemistry; Martell, A. E., Ed.; ACS Monograph 168; American Chemical Society: Washington, DC, 1978; Vol. 2. 1674. than chain growth. This is why the hydrolyzed product forms first, before the polymerization takes place. Apparently, the water molecules in the medium play an important role in the reaction. Even though the solvent and monomer were purified according to the standard procedure under dry nitrogen conditions, a trace of water molecules (ca. $50-70 \mathrm{ppm}$ ) is still present in the reaction medium, as analyzed by the Karl Fischer method, ${ }^{12}$ which explains why complexes 1-3 can initiate the polymerization. Under extremely dry conditions, we found that ethyl vinyl ether does not undergo polymerization with $\mathbf{3}$ as a catalyst within hours. However, this mixture still undergoes polymerization upon prolonged standing, presumably due to the trace amount of alcohol present in the monomers. Of course, these polymerizations are readily quenched by the addition of a base such as pyridine or triethylamine, as expected.

In summary, the proton transfer process is believed to be the initiation step for polymerization of vinyl ether catalyzed by the cationic palladium aqua complexes. The acidity of these palladium aqua complexes is currently under investigation.

\section{Experimental Section}

General Information. All reactions, manipulations, and purification steps were performed under a dry nitrogen atmosphere. Tetrahydrofuran was distilled under nitrogen from sodium benzophenone ketyl. Dichloromethane and acetonitrile were dried over $\mathrm{CaH}_{2}$ and distilled under nitrogen. Other chemicals and solvents were of analytical grade and were used as received unless otherwise stated. Complexes 1-3 were prepared as described previously. ${ }^{7}$

Nuclear magnetic resonance spectra were recorded in $\mathrm{CDCl}_{3}$ or acetone- $d_{6}$ on either a Bruker AC-E 200 or AM-300 spectrometer. Chemical shifts are given in parts per million relative to $\mathrm{Me}_{4} \mathrm{~S}$ for ${ }^{1} \mathrm{H}$ and ${ }^{13} \mathrm{C} \mathrm{NMR}$ and relative to $85 \% \mathrm{H}_{3-}$ $\mathrm{PO}_{4}$ for ${ }^{31} \mathrm{P} \mathrm{NMR}$. Due to the complicated aromatic region, chemical shifts of nonaromatic carbons were reported. Infrared spectra were measured on a Nicol et Magna-I R 550 spectrometer (Series-II) as $\mathrm{KBr}$ pellets, unless otherwise noted. Gel permeation chromatography (GPC) data were obtained from a Waters Model 590 liquid chromatograph equipped with a Lab Allience RI 2000 detector using THF as eluant at room temperature and a polystyrene cali bration curve for analyses. Differential scanning cal orimetric (DSC) measurements were carried out on a TA 2920 system.

Complex 4. To a solution of [(P $\sim \mathbf{N}) \mathrm{PdMeCl}]$ (159 mg, 0.29 $\mathrm{mmol})$ in $\mathrm{CH}_{2} \mathrm{Cl}_{2}(10 \mathrm{~mL})$ was added an equimolar amount of AgOTf in $\mathrm{CH}_{2} \mathrm{Cl}_{2}(5 \mathrm{~mL})$ and $\mathrm{H}_{2} \mathrm{O}(21 \mu \mathrm{L})$ under a nitrogen atmosphere. After it was stirred for $2 \mathrm{~h}$ at room temperature, the reaction mixture was filtered and the filtrate was concentrated to yield the crude product, which was washed with ether several times to provide the desired complex 4 (141 $\mathrm{mg}, 83 \%$ ): ${ }^{1} \mathrm{H}$ NMR $\delta 8.78(\mathrm{~s}, 1 \mathrm{H},-\mathrm{N}=\mathrm{CH}), 8.35(\mathrm{~m}, 2 \mathrm{H}), 7.65-7.01$ $(\mathrm{m}, 17 \mathrm{H}, \mathrm{Ar} \mathrm{H}), 1.74\left(\mathrm{~s}, 2 \mathrm{H}, \mathrm{OH}_{2}\right), 0.86(\mathrm{~s}, 3 \mathrm{H}, \mathrm{Pd}-\mathrm{Me}) ;{ }^{31} \mathrm{P}$ NMR $\delta 39.4 ;{ }^{13} \mathrm{C} N M R \quad \delta 168.6(-\mathrm{N}=\mathrm{CH}), 155.5-118.3$ (aromatic), $2.0\left(\mathrm{Pd}-\mathrm{CH}_{3}\right)$. Anal. Calcd for $\mathrm{C}_{27} \mathrm{H}_{25} \mathrm{~F}_{3} \mathrm{NO}_{4} \mathrm{PPd}$ : C, 49.59; H, 3.85; N, 2.14. Found C, 49.24; H, 3.68; N, 2.05 .

Complex 6. A solution of $\mathbf{1}(0.1 \mathrm{~g}, 0.18 \mathrm{mmol})$ in dichloromethane $(10 \mathrm{~mL}$ ) was pressurized with carbon monoxide (50 psi). After it was stirred for $2 \mathrm{~h}$, the reaction mixture was checked by ${ }^{31}$ P NMR to make sure that all of the complex had been converted into the palladium-acetyl complex. Ethyl vinyl ether $(0.065 \mathrm{~g}, 0.9 \mathrm{mmol})$ was then added to the above reaction mixture, and the mixture was kept stirring for $12 \mathrm{~h}$ at room

(12) Yunxiang, C.; Xin, J . Talanta 1984, 31, 556. 
temperature. The reaction mixture was concentrated, and the residue was recrystallized to give the desired complex as light yellow crystalline solids (76 mg, 61\%): IR (KBr): $1621 \mathrm{~cm}^{-1}$ $\left(v_{\mathrm{co}}\right) ;{ }^{1} \mathrm{H}$ NMR $\delta 9.3(\mathrm{~s}, 1 \mathrm{H}), 8.59(\mathrm{~m}, 2 \mathrm{H}), 8.1-7.3(\mathrm{~m}, 16 \mathrm{H})$, $5.6(\mathrm{~m}, 1 \mathrm{H}), 3.2(\mathrm{br}, 2 \mathrm{H}), 2.29(\mathrm{~s}, 3 \mathrm{H}), 2.20(\mathrm{t}, \mathrm{J}=7 \mathrm{~Hz}, 3 \mathrm{H})$. ${ }^{13} \mathrm{C}$ NMR $\delta 229.1,166.2,153.9,133.9-132.4,118.9,116.7$, 116.5, $85.2(\mathrm{~d}, \mathrm{~J}=9 \mathrm{~Hz}), 67.7,57.4,28.4,15.0 ;{ }^{31} \mathrm{P}$ NMR $\delta 35$. Anal. Calcd for $\mathrm{C}_{31} \mathrm{H}_{30} \mathrm{BF}_{5} \mathrm{NO}_{2} \mathrm{PPd}$ : $\mathrm{C}, 53.82 ; \mathrm{H}, 4.37 ; \mathrm{N}, 2.02$. Found: C, 53.76; H, 4.09; N, 1.97.

Crystallography. A crystal suitable for X-ray determination was obtained for $\mathbf{6} \cdot \mathrm{H}_{2} \mathrm{O}$ by slow evaporation of a dichloromethane/ether solution at room temperature. Cell parameters were determined by a Siemens SMART CCD diffractometer. Crystal data are as follows: $\mathrm{C}_{31} \mathrm{H}_{32} \mathrm{BF}_{5} \mathrm{NO}_{3} \mathrm{PPd}$, fw $=$ 709.76, monoclinic, $P 2_{1} / c, a=10.2058(1) \AA, b=19.8003(3) \AA$, $\mathrm{C}=15.7152(2) \AA, \alpha=90^{\circ}, \beta=108.025(1)^{\circ}, \gamma=90^{\circ}, \mathrm{V}=$ $3019.84(7) \AA^{3}, Z=4, D_{\text {calcd }}=1.561 \mathrm{Mg} / \mathrm{m}^{3}, \mathrm{~F}(000)=1440,0.20$ $\times 0.15 \times 0.15 \mathrm{~mm}, \theta=1.71-27.50^{\circ}, 18065$ reflections collected, 6793 independent reflections $\left(R_{\text {int }}=0.0472\right)$, goodness of fit on $\mathrm{F}^{2}=1.092, \mathrm{R} 1=0.0592, \mathrm{wR} 2=0.1166$ for $\mathrm{I}>$ $2 \sigma(\mathrm{I})$, largest difference peak and hole 1.004 and -0.635 e $\AA^{-3}$. Other crystallographic data are deposited as Supporting Information.

Polymerization of Vinyl Ether. The palladium complex (10 mg) was placed in a flask, which was evacuated and flushed with nitrogen three times. Vinyl ether $(2 \mathrm{~mL})$ and dichloromethane $(10 \mathrm{~mL})$ were syringed into the flask under a nitrogen atmosphere. The resulting mixture was stirred at room temperature for a certain period. After the reaction was completed, the reaction mixture was concentrated. The residue was filtered through a silica gel column with elution of chlor oform. The desired polymer was obtained upon concentration. All results are summarized in Table 1.

Poly(ethyl vinyl ether): ${ }^{1} \mathrm{H}$ NMR $\delta 3.6(\mathrm{br}, 1 \mathrm{H}, \mathrm{OCH}-)$, $3.48\left(\mathrm{br}, 2 \mathrm{H}, \mathrm{OCH}_{2}-\right), 1.70\left(2 \mathrm{H},-\mathrm{CH}_{2}-\right), 1.2\left(\mathrm{t}, 3 \mathrm{H},-\mathrm{CH}_{3}\right)$; ${ }^{13} \mathrm{C}$ NMR $\delta 74\left(\mathrm{OCH}_{2}\right), 64(\mathrm{OCH}-), 40\left(-\mathrm{CH}_{2}-\right), 16\left(-\mathrm{CH}_{3}\right)$.

Poly(2,3-dihydrofuran): ${ }^{1} \mathrm{H}$ NMR $\delta 3.52-3.72(\mathrm{br}, 3 \mathrm{H}$, $\mathrm{OCH}-$ and $\left.\mathrm{OCH}_{2}-\right)$, 1.86-2.32 (br, $3 \mathrm{H},-\mathrm{CH}-$ and $\left.-\mathrm{CH}_{2}-\right)$; ${ }^{13} \mathrm{C}$ NMR $\delta 79-84(\mathrm{OCH}-), 65-67\left(\mathrm{OCH}_{2}-\right), 43-47(-\mathrm{CH}-)$, $25-30\left(-\mathrm{CH}_{2}\right)$.

Acknowledgment. We thank the National Science Council (Grant No. NSC90-2113-M 002-38) for financial support.

Supporting Information Available: Complete description of the X-ray crystallographic structure determination of 6. $\mathrm{H}_{2} \mathrm{O}$, incl uding atomic coordinates, isotropic and ani sotropic thermal parameters, bond distances and angles, and hydrogen coordinates. This material is available free of charge via the Internet at http://pubs.acs.org.

OM020662S 